\title{
The Effect of Fullerenol Combined with Cisplatin on the Proliferation of Cervical Cancer HeLa Cells
}

\author{
Yuan Niu1, Chao Yan²* \\ ${ }^{1}$ Medical College, Qingdao University, Qingdao, China \\ ${ }^{2}$ Department of Radiotherapy Oncology, Qilu Hospital of Shandong University (Qingdao), Qingdao, China \\ Email: "qdyanchao@aliyun.com
}

Received 4 March 2016; accepted 28 March 2016; published 31 March 2016

Copyright (C) 2016 by authors and Scientific Research Publishing Inc.

This work is licensed under the Creative Commons Attribution International License (CC BY). http://creativecommons.org/licenses/by/4.0/

(c) (i) Open Access

\begin{abstract}
This study aimed to investigate the effect of fullerenol combined with cisplatin on the proliferation of cervical cancer HeLa cells in order to provide new ideas and laboratory theoretical basis for the clinical treatment of cervical cancer. Cervical cancer cell line HeLa cells in vitro were treated with different concentrations of fullerenol, different concentrations of cisplatin, and different concentrations of fullerenol combined with cisplatin, after $24 \mathrm{~h}, 48 \mathrm{~h}, 72 \mathrm{~h}$, microscope changes in cell morphology; MTT assay was used to determine the effect of drugs on the proliferation of HeLa cells. Fullerenol and cisplatin alone can inhibit the proliferation of HeLa cells in a dose-dependent and time-dependent manner; compared with cisplatin alone, different concentrations of fullerenol combined with cisplatin significantly increased the apoptosis rate of HeLa cells $(P<0.05)$. The inhibition of fullerenol combined with cisplatin on HeLa cells in vitro is more significant, resulting in a stronger anti-cancer effect.
\end{abstract}

\section{Keywords}

Fullerenol, Cisplatin, HeLa Cells, Proliferation, Apoptosis

\section{Introduction}

Cervical cancer is one of the most common female cancers; female cancer mortality rate was 3.28/100,000. In China, about 2 - 3 million women were died of cervical cancer every year; the incidence rate of cervical cancer

*Corresponding author. 
in young women is increasing [1] [2]. Surgery and radiotherapy are the main treatments for cervical cancer; in the early stage of the disease surgical treatment timely is taken, and in most advanced stage radiotherapy is taken. Application of chemotherapy in cervical cancer at home and abroad has carried out basic and clinical research in recent years and achieved satisfactory results, which result in improving 5-year survival rate and determining the status of chemotherapy in the treatment of cervical cancer [3]-[7]. However, the disadvantages of chemotherapy drugs are poor specificity and easy resistance; in response to these shortcomings, fullerenol may provide a new method to improve the problem. Fullerenol is a water-soluble fullerene derivative by introducing 18 - 20 hydroxy group at fullerene carbon, has a variety of biological activities, and can cause cell autophagy and induce apoptosis effect characterized by a dose-dependent and time-dependent relationship [8]; in addition, it can clear free radicals of blood and superoxide radicals generated by xanthine and xanthine oxidase in aqueous solution [9]. In this regard, fullerenol has a higher biomedical value worth exploring. This study aimed to explore the possibility of producing safer and more effective anti-tumor effect with fullerenol combined with cisplatin by observing the changes of fullerenol, cisplatin and fullerenol combined with cisplatin on HeLa cells proliferation and comparing different fullerenol cisplatin and fullerenol cisplatin monotherapy effect, which provided experimental evidence and theoretical basis by using fullerenol in the treatment of cervical cancer.

\section{Materials and Methods}

\subsection{Drugs and Reagents}

Fullerenol (supplied by Professor Dianbao Chen, Qingdao University of Science and Technology), cisplatin (Jiangsu Stockhausen Pharmaceutical Co., Ltd.), dimethyl sulfoxide (DMSO, Sigma Company), MTT (MTT) was purchased from Haibi sky Biotechnology Co., Ltd., $\mathrm{CO}_{2}$ incubator, automatic microplate reader.

\subsection{Cell Culture and Subculture}

Cervical cancer cell line HeLa cells (Shanghai Cell Bank), culture medium containing 10\% fetal calf serum and $0.05 \mathrm{~g} / \mathrm{L}$ penicillin and $0.05 \mathrm{~g} / \mathrm{L}$ streptomycin and RPMI1640 medium (Gibco Company); containing 5\% $\mathrm{CO}_{2}$, $37^{\circ} \mathrm{C}$ saturated humidity incubator; grown for 2 - 3 days; $0.25 \%$ trypsin digestion and passage. Logarithmic growing cells for experiments.

\subsection{Fullerenol Formulated Solution}

Different concentrations of fullerenol were treated with DMEM medium without fetal calf serum, then filter sterilization by $0.22 \mathrm{~mm}$ microporous membrane when it will be used.

\subsection{Inverted Microscope to Observe the HeLa Cell Morphological Changes}

Logarithmic growth phase of HeLa cells after counting to $105 / \mathrm{mL}$ concentration seeded in culture flasks of 25 $\mathrm{cm}^{2}$ bottle $2 \mathrm{~mL}$, after being adherent cells to be administrated drugs, fullerenol group (concentrations of 2.5, 5, $10 \mathrm{ug} / \mathrm{mL}$ ), cisplatin $(1,2.5,5,10 \mathrm{ug} / \mathrm{mL}$ ), the combined group (5 ug/mL cisplatin $+2.5,5,10 \mathrm{ug} / \mathrm{mL}$ fullerenol), after 24, 48, 72 hours, they were observed the cell morphology by using inverted microscope.

\subsection{MTT Cell Viability Assay}

Experimental HeLa cells were divided into four groups: control group (Only add fresh medium); fullerenol group (concentration, respectively $2.5 \mathrm{ug} / \mathrm{mL}, 5 \mathrm{ug} / \mathrm{mL}, 10 \mathrm{ug} / \mathrm{mL})$; cisplatin $(1 \mathrm{ug} / \mathrm{mL}, 2.5 \mathrm{ug} / \mathrm{mL}, 5 \mathrm{ug} / \mathrm{mL}, 10$ $\mathrm{ug} / \mathrm{mL}$ ); the combined group ( $5 \mathrm{ug} / \mathrm{mL}$ cisplatin $+2.5 \mathrm{ug} / \mathrm{mL}, 5 \mathrm{ug} / \mathrm{mL}, 10 \mathrm{ug} / \mathrm{mL}$ fullerenol). Each group provided three holes, the drug concentration is diluted by medium to experiment with various concentrations. Making HeLa cells in logarithmic phase into single cell suspension adjust the cell concentration of $2 \times 10^{4} / \mathrm{mL}$, which were seeded in 96 -well culture plate and set $37.0^{\circ} \mathrm{C}, 5 \% \mathrm{CO}_{2}$ culture box to culture for 24 hours. The experimental groups were added with different concentrations of cisplatin and fullerenol making the final concentration meet the above requirements, while the control group was added with equal volume of culture medium. After 24, 48, 72 hours, the plates were scheduled for the detection of each well $20 \mu \mathrm{MTT}(5 \mathrm{mg} / \mathrm{mL})$ solution in $\mathrm{CO}_{2}$ incubator incubated for $4 \mathrm{~h}$, then the supernatant was discarded, trace shaker shaken for 15 minutes after $150 \mu \mathrm{l}$ DMS0 each well, the absorbance was measured OD values of each well using a microplate reader at 490 
$\mathrm{nm}$ finally. The experiment was repeated three times. Calculated growth inhibition rate (IR) of HeLa cells according to the following formula. IR = (1-average OD value of experimental group/average OD value of control group) $\times 100 \%$

\subsection{Statistical Analysis}

All statistical analyse were performed using SPSS software (version 17.0, SPSS Inc., USA). Samples were compared using the t test. Significance level $\alpha=0.05$. $\mathrm{P}<0.05$ was considered statistically significant.

\section{Result}

\subsection{Morphological Observation of Apoptosis under Inverted Microscope}

After 24 hours, HeLa cells of untreated group were epithelial type; cell morphology presented flat or irregular or polygonal; the cell grew with adherence; the connection between the cells were more closely. However, HeLa cells of different concentrations of fullerenol and cisplatin showed different degrees of morphological changes, showing some cell bodies became smaller and smoother, burr-like membrane was shrunken; cells containing highly concentrated chromatin nuclei, chromatin condensation, and some have more increased cytoplasmic fragmented cells from adherent state off, suspended in a culture medium. HeLa cells of different concentrations of fullerenol combined with cisplatin showed that cell morphology were similar to the cisplatin group, while cell shrinkage were more apparent and the number of cells reduced obviously (Figures 1-4). With incubation time and the increase of drug concentration, the cells exfoliated increased gradually and the morphology changes more obviously. The fullerenol combined with cisplatin group, with synergies to strengthen the two drugs, the more obvious morphological changes that cell.

\subsection{Growth Inhibition of Cisplatin on HeLa Cells}

MTT analysis showed that the inhibition rate of cisplatin group $(1 \mathrm{ug} / \mathrm{mL})$ was higher than the control group

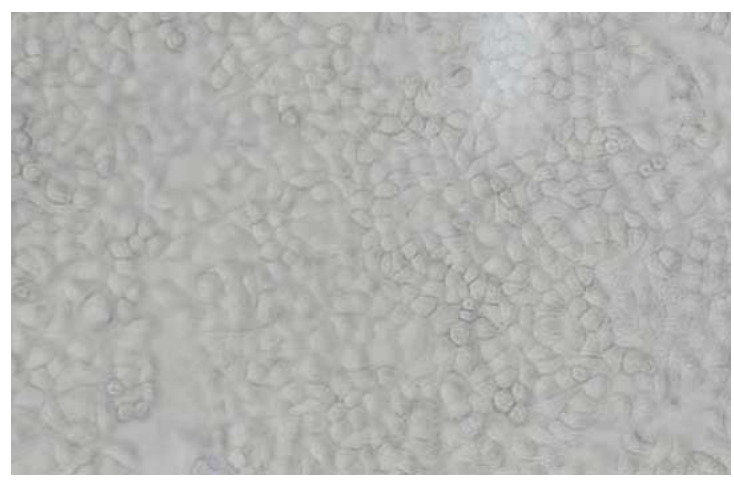

Figure 1. Control group $(\times 40)$.

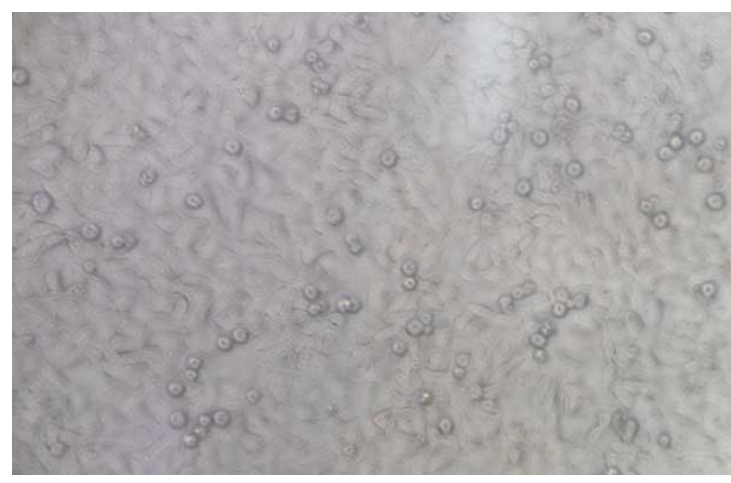

Figure 2. Cisplatin group $(\times 40)$. 


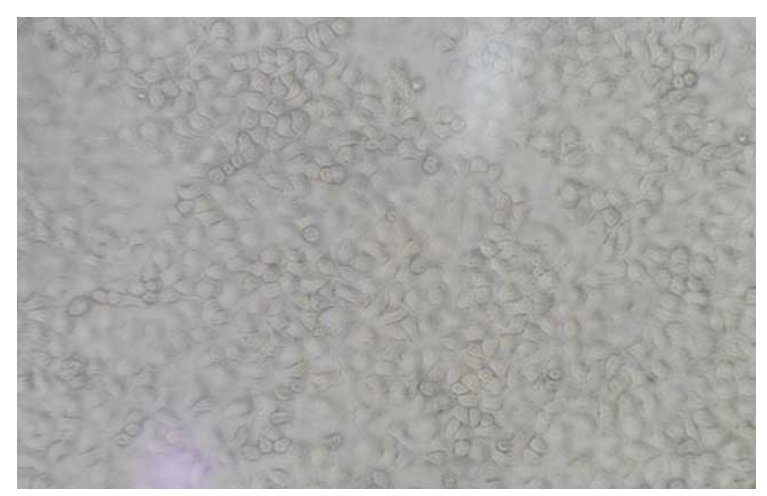

Figure 3. Fullerenol group $(\times 40)$.

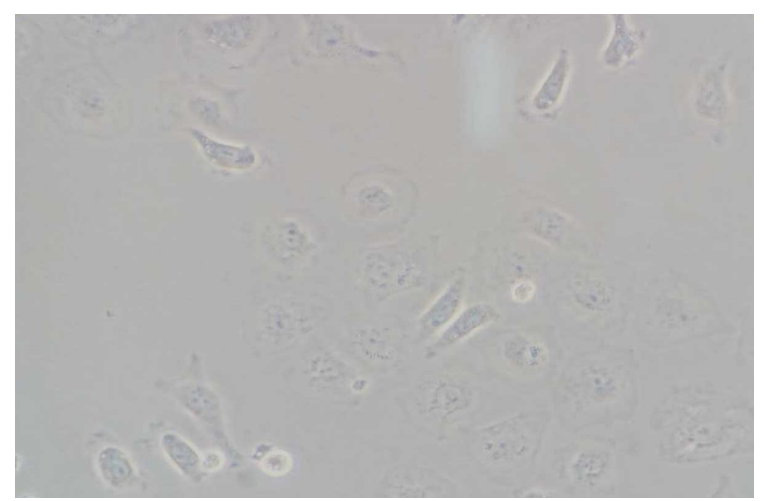

Figure 4. Combined group $(\times 40)$.

from the beginning $24 \mathrm{~h}$, and continued to $72 \mathrm{~h}$. With the extension of time, the inhibition rate was significantly increased. After increasing the concentration of cisplatin, this trend is more obvious. Experimental results show that the growth of HeLa cells was significantly inhibited, the inhibition rate not only with the increase of drug concentration increased, but also with the extension of treatment time increased. Compared with the control group, treated with different concentrations of cisplatin in HeLa cells for 24 hours, 48 hours and 72 hours, the differences were statistically significant $\mathrm{P}<0.01$ (Table 1 ).

\subsection{Growth Inhibition of Fullerenol on HeLa Cells}

MTT analysis showed that the fullerenol group compared with control group, each concentration (2.5, 5.0, 10.0, $\mathrm{ug} / \mathrm{mL}$ ) of fullerenol was dealt with the $24 \mathrm{~h}$, the inhibition rate began to rise and continued to $72 \mathrm{~h}$; inhibition rate showed an increasing trend from low concentration $(2.5 \mathrm{ug} / \mathrm{mL})$ to the high mass concentration $(10.0$ $\mathrm{ug} / \mathrm{mL})$. After $24,48,72 \mathrm{~h}$, cell inhibition rate was significantly lower than normal control group $(\mathrm{P}<0.05)$. Thus informed that the growth of fullerenol on HeLa cells was more significantly, which inhibited the rate of inhibition with the drug concentration and prolonged increases. Compared with the control group, treated with different concentrations of fullerenol in HeLa cells for 24 hours, 48 hours and 72 hours, the differences were statistically significant $\mathrm{P}<0.01$ (Table 2).

\subsection{Effect on HeLa Cells Growth Using Different Concentrations of Fullerenol in Combination with Cisplatin}

Respectively, with three kinds of concentration of fullerenol (2.5, 5, $10 \mathrm{ug} / \mathrm{mL}$ ) combined with cisplatin (5 $\mathrm{ug} / \mathrm{mL})$ on Hela cell for $24,48,72 \mathrm{~h}$, the result shown that fullerenol (2.5 ug/mL) combined with cisplatin, its inhibition rate have no difference compared with cisplatin alone, $\mathrm{P}>0.05$. When fullerenol $(5,10 \mathrm{ug} / \mathrm{mL}) \mathrm{com}$ bined with cisplatin $(5 \mathrm{ug} / \mathrm{mL})$, its inhibition rate was higher than the same application of cisplatin group and fullerenols group, the result was statistically significant, $\mathrm{P}<0.01$ (Table 3 ). 
Table 1. Inhibition rate of different concentrations of cisplatin 24, 48, 72 hours on HeLa cells (Mean $\pm \mathrm{SD}, \%$ ).

\begin{tabular}{cccc}
\hline \multirow{2}{*}{ Cisplatin dose } & \multicolumn{3}{c}{ Treatment time } \\
\cline { 2 - 4 } & $24 \mathrm{~h}$ & $48 \mathrm{~h}$ & $72 \mathrm{~h}$ \\
\hline Control group & $0.00 \pm 0.000$ & $0.00 \pm 0.000$ & $0.00 \pm 0.000$ \\
$1.0 \mathrm{ug} / \mathrm{mL}$ & $8.65 \pm 0.494^{*}$ & $19.10 \pm 1.017^{*}$ & $26.93 \pm 0.975^{*}$ \\
$2.5 \mathrm{ug} / \mathrm{mL}$ & $16.79 \pm 0.953^{*}$ & $29.86 \pm 0.807^{*}$ & $39.10 \pm 1.052^{*}$ \\
$5.0 \mathrm{ug} / \mathrm{mL}$ & $20.85 \pm 0.921^{*}$ & $38.33 \pm 1.115^{*}$ & $50.62 \pm 0.702^{*}$ \\
$10.0 \mathrm{ug} / \mathrm{mL}$ & $27.56 \pm 1.396^{*}$ & $53.24 \pm 0.924^{*}$ & $69.10 \pm 1.240^{*}$ \\
\hline
\end{tabular}

Note: ${ }^{*} \mathrm{P}<0.01$ compared with control group $(0 \mu \mathrm{g} / \mathrm{mL})$.

Table 2. Inhibition rate of different concentrations of fullerenol 24, 48, 72 hours on HeLa cells (Mean \pm SD, \%).

\begin{tabular}{cccc}
\hline & \multicolumn{3}{c}{ Treatment time } \\
Fullerenol dose & $24 \mathrm{~h}$ & $48 \mathrm{~h}$ & $72 \mathrm{~h}$ \\
\cline { 2 - 4 } & $0.0000 \pm 0.0000$ & $0.0000 \pm 0.0000$ & $0.0000 \pm 0.0000$ \\
\hline Control group & $0.0120 \pm 0.0014^{\#}$ & $0.0245 \pm 0.0021^{\#}$ & $0.0540 \pm 0.0042^{\#}$ \\
$5.0 \mathrm{ug} / \mathrm{mL}$ & $0.2450 \pm 0.0042^{\#}$ & $0.2670 \pm 0.0028^{\#}$ & $0.2835 \pm 0.0021^{\#}$ \\
$10.0 \mathrm{ug} / \mathrm{mL}$ & $0.2840 \pm 0.0014^{\#}$ & $0.3150 \pm 0.0042^{\#}$ & $0.3725 \pm 0.0078^{\#}$ \\
\hline
\end{tabular}

Note: ${ }^{\#} \mathrm{P}<0.01$ compared with control group $(0 \mu \mathrm{g} / \mathrm{mL})$.

Table 3. Inhibition rate of different concentrations of fullerenol combined with cisplatin 24, 48, 72 h on HeLa cells (Mean \pm SD, \%).

\begin{tabular}{|c|c|c|c|}
\hline \multirow{2}{*}{$\begin{array}{l}\text { Fullerenol concentration } \\
\text { with } 5 \mathrm{ug} / \mathrm{mL} \text { cisplatin } \\
\text { in combination }\end{array}$} & \multicolumn{3}{|c|}{ Treatment time } \\
\hline & $24 \mathrm{~h}$ & $48 \mathrm{~h}$ & $72 \mathrm{~h}$ \\
\hline Control group & $20.850 \pm 0.9210$ & $38.330 \pm 1.1150$ & $50.620 \pm 0.7020$ \\
\hline $2.5 \mathrm{ug} / \mathrm{mL}$ & $22.308 \pm 0.0065$ & $40.113 \pm 0.1834$ & $51.683 \pm 0.0082$ \\
\hline $5.0 \mathrm{ug} / \mathrm{mL}$ & $22.326 \pm 0.0090^{\wedge}$ & $40.150 \pm 0.0044^{\Delta}$ & $51.707 \pm 0.0045^{\wedge}$ \\
\hline $10.0 \mathrm{ug} / \mathrm{mL}$ & $22.349 \pm 0.0045^{\boldsymbol{\Lambda}}$ & $40.171 \pm 0.0075^{\boldsymbol{\Lambda}}$ & $51.724 \pm 0.0050^{\boldsymbol{\Lambda}}$ \\
\hline
\end{tabular}

Note: ${ }^{\star} \mathrm{P}<0.05$ compared with control group (cisplatin 5 ug/mL).

\section{Discussion}

Apoptosis is a morphological changes, nuclear morphological changes which are typical characteristics of apoptosis, changes in cell morphology is thus reliably determine the standard apoptosis [10]. Chemotherapy based on cisplatin has become the standard chemotherapy in comprehensive treatment of cervical cancer. Some experiments have found that cisplatin can inhibit protein expression in HeLa cells of cervical cancer cell lines, promote cell apoptosis significantly and inhibit the growth to achieve a therapeutic effect, which is a certain age and dose effect relationship [11]. But drugs can cause serious adverse reactions, long-term large number of applications on the body can cause damage to normal tissue, and lead to cancer resistant to chemotherapy response. Fullerene C60 is a new ball-shaped molecule found in the 1980s, all composed of carbon atoms, it has a special hollow cage-like structure, the diameter of $0.71 \mathrm{~nm}$. Fullerenol is a water-soluble derivative of fullerene C60, after the appropriate light intensity and irradiation time can fullerenol transitions from the ground state to an excited state, excited state fullerenol can be effective molecular oxygen quenching, resulting in free radical C60, 
$\mathrm{OH}, \mathrm{O}_{2}$ or a single state oxygen ${ }^{1} \mathrm{O}_{2}$, these free radicals and singlet oxygen $\mathrm{O}_{2}$ can react with proteins, DNA and lipid film response, causing protein oxidation, DNA strand breaks, lipid peroxidation thereby destroying cancer structure of the cell membrane to induce apoptosis [12]. Professor Chen Dianbao and Professor Wang Zhijie of Wuhan University applied fullerenol -C60 $(\mathrm{OH}) \mathrm{n}, \mathrm{C60}(\mathrm{OH}) \mathrm{n} / \mathrm{C} 70(\mathrm{OH}) \mathrm{n}(\mathrm{n}=18-20)$ to carry on the growth inhibition test of human laryngeal cancer cell line Hep-2 and human cervical cancer cell line HeLa, observed the effects of apoptosis of cancer cells induced, and was first discovered in the dark light conditions, low concentration of fullerenol can also induce the apoptosis of cancer cells in a dose and time-dependent. The intensity of DNA staining in cancer cells treated with fullerenol decreased, the dead cells had the morphological characteristics of apoptotic cells and the cytoskeleton was severely damaged. [13]. Experiments have already made -C60 through the process of regulating autophagy to enhance the efficacy of chemotherapy and reduce the resistance of the biological function of cancer cells, which suggests a potential value of C60 becomes adjuvant chemotherapy [8]. Gordana Bogdanovi and other studies have shown that fullerenol can inhibit human breast cancer cells: T47D, MCF-7 cells and the activity of MDA-MB-231 in a concentration of $0.5-7.9 \mu \mathrm{g} / \mathrm{mL}$, after 24, 48, $72 \mathrm{~h}$ cultivation, fullerenol maximum cytotoxicity of $40 \%-45 \%$, and fullerenol is a potent hydroxyl radical scavenger [14].

In this experiment, MTT assay showed weak proliferation inhibitory effect with fullerenol at a dose of 2.5 $\mu \mathrm{g} / \mathrm{mL}$ on HeLa cells, when the dose was increased to when $10 \mu \mathrm{g} / \mathrm{mL}$, the inhibitory effect on HeLa cells gradually increased and showed a time-dependent manner, that is to say, with increasing treatment time, the inhibition rate increased significantly, which was statistically significant. This experiment also shows cisplatin on the growth of HeLa cells was inhibited, and showed a dose-dependent and time-dependent manner. After this experiment, we choose moderate-dose cisplatin $(5 \mu \mathrm{g} / \mathrm{mL})$ to combine with fullerenol $(2.5,5,10 \mu \mathrm{g} / \mathrm{mL})$, after $24 \mathrm{~h}$, $48 \mathrm{~h}, 72 \mathrm{~h}$ respectively, cell inhibition rates higher than fullerenol alone, so drug combination enhanced inhibition of human HeLa cells, there was no difference in addition of fullerenol with a concentration of $2.5 \mu \mathrm{g} / \mathrm{mL}$. That compared with cisplatin alone, fullerenol with cisplatin significantly increases the effect of cisplatin, to achieve the same effect in reducing the use of lower amounts of cisplatin. Biological effects of fullerenol may be associated with ${ }^{1} \mathrm{O}_{2}$ and $\mathrm{OH}$ - by system produce, then resulting in cell apoptosis, but the mechanism of action of the specific need further study.

\section{Conclusion}

In conclusion, systemic chemotherapy can improve the resection rate or radiosensitivity before surgery or radiotherapy in cervical cancer, but the side effects of acquired drug resistance of tumor cells often affect the overall effectiveness of chemotherapy, so finding a drug that can enhance the effectiveness of chemotherapy is the key to improve the success rate of chemotherapy and the survival rate of patients. Because of natural resistance and low toxicity characteristics of fullerenol, it has broad application prospects in cancer chemotherapy. The experimental results show that fullerenol has inhibitory effect and synergistic effect on cervical HeLa cells, which has a stronger anti-tumor effect, but due to its certain difference between the in vitro and in vivo drug interaction, it is necessary to further confirm the reliability, so that clinical treatment of cervical cancer tries new chemotherapeutic agents and regimens provide certain theoretical basis.

\section{Acknowledgements}

This work was supported by Laboratory of Medical College of QingDao University. We would like to thank Chao Yan for invaluable contributions during this collaboration.

\section{References}

[1] Ying, Q., Xia, Q.M., Zheng, R.S., Zhang, S.W. and Chen, W.Q. (2013) China Cervical Cancer Incidence and Mortality in 2009. Chinese Journal of Cancer, No. 8, 612-616. (In Chinese)

[2] Duan, Y.C. and Hu, P. (2007) Progress in the Treatment of Cervical Cancer. Foreign Medical Sciences, No. 2, 137-139. (In Chinese)

[3] Sardi, J.E., Boixadera, M.A. and Sardi, J.J. (2005) Neoadjuvant Chemotherapy in Cervical Cancer: A New Trend. Current Opinion in Obstetrics and Gynecology, 17, 43-47. http://dx.doi.org/10.1097/00001703-200502000-00008

[4] Miglietta, L., Franzone, P., Centurioni, M.G., et al. (2006) Aphase Trial with Cisplatin-Paclitaxel Cytotoxic Treatment and Concurrent External and Endocavitary Radiation Therapy in Locally Advanced or Recurrent Cervical Cancer. 
Oncology, 70, 19-24. http://dx.doi.org/10.1159/000091182

[5] DuPont, N.C. and Monk, B.J. (2006) Chemotherapy in the Management of Cervical Carcinoma. Clinical Advances in Hematology \& Oncology, 4, 279.

[6] Huang, M.N., Wu, L.Y. and Gao, J.Z. (2004) Cervical Cancer Progression. Chemoradiotherapy Magazine, 2, 320-322. (In Chinese)

[7] Yin, W.B., Yu, Z.H., Xu, G.Z., et al. (2008) Cancer Radiation Therapy. 4th Edition, China Union Medical University Press, Beijing, 1350-1372. (In Chinese)

[8] Yang, W.H., Chen, D.B. and Wang, X.M. (2004) Biology and Biomedical Research Applications of Fullerenes and Fullerenols. Progress in Pharmaceutical Sciences (Chinese), 28, 243-246.

[9] Chiang, L.Y., Lu, F.J. and Lin, J.T. (1995) Free Radical Scavenging Activity of Water-Soluble Fullerenols. Journal of the Chemical Society, Chemical Communications, 12, 1283-1284. http://dx.doi.org/10.1039/c39950001283

[10] Liu, F.X. and Song, Y. (2010) Effect SJAMP on Apoptosis of HeLa and Bax, Bcl-2 Gene Expression. Practical Journal of Medicine, 26, 2089-2091.

[11] Liu Y.Q., Xing, H., Han, X.B., et al. (2006) Cisplatin-Induced Apoptosis in HeLa Cells and Its Mechanism of Action. Chinese Journal of Clinical Oncology, 33, 1-4. (In Chinese)

[12] Maeda, R., Noiri, E., Isobe, H., et al. (2008) A Water-Solube Fullerene Vesicle Alleviates Angiotensin II-Induced Oxidative Stress in Human Unbilical Venous Endothelial Cells. Hypertension Research, 31, 141-151. http://dx.doi.org/10.1291/hypres.31.141

[13] Yang, W.J. (2008) Role of Nanomaterials in the Treatment of Cancer Research. Thesis, University of Science and Technology of China, Hefei. (In Chinese)

[14] Bogdanovic, G., Kojic, V., Dordevic, A., et al. (2004) Modulating Activity of Fullerol C60(OH)22 on Doxorubicin-Induced Cytotoxicity. Toxicology in Vitro, 18, 629-637. http://dx.doi.org/10.1016/j.tiv.2004.02.010 